Linguagem em (Dis)curso - LemD, v. 9, n. 1, p. 81-106, jan./abr. 2009

\title{
MAKING SENSE OF CLASSROOM INTERACTION VIA A MULTIPLE-METHOD DESIGN: SOCIAL, EXPERIENTIAL AND EPISTEMOLOGICAL DIMENSIONS
}

Irit Kupferberg*

Sarah Shimoni**

Esther Vardi-Rath ${ }^{* * *}$

Title: This article explores the contribution of a multiple-method design to the study of classroom interaction. The theoretical and methodological frameworks of three constructivist discourse-oriented methods (i.e., Institutional Speech Event Analysis, The Four-World Method and Grounded Theory) are summarized and the same text is submitted to three independent text analyses. The article shows that a multiple-method design is conducive to the discovery of implicit meanings related to social, experiential and epistemological aspects of classroom interaction.

Keywords: classroom interaction; discourse analysis; multiple-method design; positioning; grounded theory.

The fabric of schooling is woven of linguistic interaction. (ADGER, 2001, p. 503)

\footnotetext{
* Professor at the Levinsky College of Education, Tel Aviv, Israel. PhD in Discourse Analysis. Email: <kupir@macam.ac.il>.

** Professor at the Mofet Institute for Professional Development of Teacher Educators, Tel Aviv, Israel.PhD in Education Studies. E-mail: <shsara@macam.ac.il>.

*** Professor at the Kaye College of Education, Beer-Sheva, Israel. PhD in Discourse Analysis. Email: <esterv@macam.ac.il>.
} 


\section{INTRODUCTION}

Following Jackson's (1968), classrooms have often been defined as territories that are both very familiar and complex. This duality has urged many scholars to explore what goes on behind the classroom closed doors. The discursive turn provided these scholars with theoretical and methodological frameworks that enabled them to examine the collaborative construction of meaning closely (ADGER, 2001; ANWARD, 1997; BLOOME et al., 2005; CAZDEN, 1988; EDWARDS; WESTGATE, 1994; MEHAN, 1979; PELEDELHANAN; BLUM-KULKA, 2006; THOLANDER; ARONSSON, 2003; VARDI-RATH, 2002; YOUNG, 1999; WELLS, 1999) in multicultural educational settings (EDWARDS, 1999; HYMES, 1997).

Our study attempts to meet the challenge of exploring meaning in classroom interaction by using a multiple-method design "in which more than one research method $[. .$.$] is used to answer research questions"$ (TASHAKKORI; TEDDLIE, 2003, p. 712). Accordingly, in this paper we use three constructivist (LINCOLN; GUBA, 1998) discourseoriented methods (TITSCHER et al., 2000), sharing the assumption that classroom interaction can be explored through focus on discourse language produced in a particular context (SCHWANDT, 2001). The connection between discourse and context is succinctly defined in the following citation: "In the study of discourse as action and interaction contexts are crucial. Indeed, the main distinction between abstract discourse analysis and social discourse analysis is that the latter takes the context into account" (VAN DIJK, 1997, p.11).

The three methods selected are Institutional Speech Event Analysis (ISEA) (VARDI-RATH; BLUM-KULKA, 2005), The FourWorld Method (FWM) (KUPFERBERG; GREEN, 2005) and Grounded Theory (GT) (GLASER, 1978; GLASER; STRAUSS, 1967). In the following sections of the article, we present a short introduction focusing on the study of classroom discourse. Then, the theoretical and methodological frameworks of the methods are summarized, accompanied by three independent analyses of the same text - an excerpt taken from a third-grade science lesson about the major food 
groups. Finally, our discussion highlights the contribution of a multiplemethod design to the study of classroom interaction.

\section{THEORETICAL FRAMEWORK: EXAMINING CLASSROOM DISCOURSE VIA MICRO AND MACRO-ANALYTIC LENSES}

Classroom discourse analysts are often inspired by institutional conversation analysis (ICA) (DREW; HERITAGE, 1992). Following micro-analytic conversation analysis (SACKS, 1992), ICA foregrounds the local construction of institutional life as it is unfolded in real-time (THORNBORROW, 2002). Espousing this view, the discourse analyst describes and interprets what (i.e., the content) interlocutors say and how (i.e., the form) it is manifested in their interactional discourse, shying away from a priori statements. In other words, this approach leaves agency, opportunity and conditions of possibility in the interlocutors' hands (HOLSTEIN; GUBRIUM, 2000).

For example, exploring classroom discourse via a micro-analytic lens, Peled-Elhanan and Blum-Kulka (2006) identified three interactional genres characteristic of the Israeli classrooms they explored. Socratic dialogue is a topical discussion jointly constructed by the teacher and the students. Pseudo-dialogue and monologue in disguise take place when teachers present the class with topical discussions, but evaluate the students' contributions in terms of "pedagogic or regulative discourse" (p. 120). Peled-Elhanan and Blum-Kulka (2006) show that pseudo-dialogue and monologue in disguise were dominant in the classes they observed.

Critical discourse analysts (CDA) (ROGERS et al., 2005) adopt a stance on interaction which is guided by the idea that discourse analysis should move from description and interpretation of classroom interaction "to explanation of how discourse systematically constructs versions of the social world" (ROGERS et al., 2005, p.371). To this end, critical discourse analysts often define a priori concepts such as asymmetry, hegemony, power, ideology, class, gender, race, discrimination and interests (VAN DIJK, 2001) before they set out to explore meaning-making processes in discourse. 
We have seen that ICA advocates a micro-analytic study of discourse that is by and large free from guiding theoretical principles, whereas CDA encourages the researcher to equip himself with explanatory macro principles. The two approaches seem incompatible at first glance. However, current discourse-oriented studies advocate the construction of an interface between micro and macro-perspectives on discourse analysis (BAMBERG, 2004; HOLSTEIN; GUBRIUM, 2000; KUPFERBERG; GREEN, 2005).

These studies acknowledge the importance of micro text-analysis that is sensitive to changes in the participants' discursive positioning in relation to each other, but at the same time emphasize the need to relate the findings to theory. Accordingly, during and after the process of data analysis the researcher seeks to establish a link with theory (HOLSTEIN; GUBRIUM, 2000), instead of using it as an a priori framework that determines the course of the study.

Bearing in mind the micro and macro-perspectives on classroom discourse outlined in this section, this article will present three methods of analysis. The methods can be characterized in terms of two dimensions: the use of a priori guiding concepts and the focus on content/form. ISEA, the first method, seeks to explore asymmetry and power relations in the text by focusing on language forms used by interlocutors. FWM and GT describe and interpret the form and content of discourse, without imposing a priori guiding definitions. The following research question guided our study: What is the contribution of a multiple-method design to the understanding of classroom interaction?

\section{A MULTIPLE-METHOD STUDY OF CLASSROOM INTERACTION}

In this section, we present the theoretical and methodological frameworks of the three methods, accompanied by independent textanalyses. Our unit of analysis is a turn (i.e. the time when one party speaks until a change takes place and another party takes over) (TEN HAVE, 1999). The choice of this unit is important for analyses focusing on classroom interaction. In addition, ISEA required the division of the 
turn into utterances (i.e., a speech unit which is autonomous in terms of its pragmatic and communicative function) (QUIRK et al., 1985).

The text is presented in Example 1. This is an excerpt from a third grade science lesson in a heterogeneous class in an urban elementary school whose pupils come from a middle socio-economic background. The lesson constitutes a component of the science program focusing on the major food groups and their relevance to one's health.

Example 1 - An excerpt from a third grade science lesson:

1 Teacher: So, if that's the case, what can we say - what ingredients are there in bread?

2 Student 1: Vitamins.

3 Teacher: Good. Meir says vitamins, he sees it here.

Do you see bread in the Vitamins column?

Do you see bread?

6

7

So, when we eat bread, our body also gets vitamins.

Only vitamins?

8

What else does it have, Amit?

9

Effie's gone back to his seat without permission.

12 Student 2: Carbohydrates.

13 Teacher: Carbohydrates, good.

What else, Roi?

We saw bread in the Carbohydrates column as well, and what else?

Where else?

17 Student 3: Proteins.

18 Student 4: In Salts and Vitamins. [All the students are talking at the same time.]

19 Student 5: Orna, in the Food Ingredient Chart on page eleven, there's everything in bread

20 Teacher: We haven't gotten there yet, haven't gotten there yet

21 Student 5: But there's everything in bread there.

22 Teacher: Just a second. We'll get there in a second.

23 Student 5: I've already gotten there. 
24 Teacher: Listen to what you're going to do for homework very, very easy work,

25 Especially those who listened.

26 Neta.

27 I've already called on you several times today. I wanted to hear an answer and I haven't managed to get an answer. But talk - you talk. Listen to what you're going to do at home - very, very easy work. Everyone looks at me. We're talking; we want to keep our bodies healthy, right?

So the first thing I have to remind you of every day is not to swing so that you

don't fall

OK, uh, who has something to say?

\subsection{Institutional Speech Event Analysis (ISEA)}

\subsubsection{Theoretical framework}

Institutional Speech Event Analysis (ISEA) is inspired by the ethnography of communication (HYMES, 1972, 1997), which analyzes patterns of communication as part of cultural knowledge and behavior, and pragmatics (AUSTIN, 1962; SEARLE, 1969, 1975), which examines the communicative intentions of the various speech acts, and also deals with the mismatch between utterance meaning and speaker meaning (GRICE, 1975; DASCAL, 1983). ISEA also draws on interactional sociolinguistics (GUMPERZ, 1982, 1992), which analyzes the "participant structure" on the basis of contextualization cues, conversation analysis (SCHEGLOFF; SACKS, 1973), which affords a thorough examination of turn exchange in discourse and Goffman's theory, which enriches the analysis of the social interaction in the context of the public and formal domain (GOFFMAN, 1959, 1967, 1981). 
ISEA (VARDI-RATH; BLUM-KULKA, 2005) aims at understanding social interaction during institutional speech events. The analysis seeks to foreground speech strategies used by interlocutors for building and maintaining power relations, and/or for saving face (i.e., "The positive social value a person effectively claims for himself by the line others assume he has taken during a particular contact") (GOFFMAN, 1967, p. 5).

Following this theoretical framework, ISEA regards the lesson as an institutional speech event which takes place in frontstage (i.e., in the public and formal domain) (GOFFMAN, 1959). It is an asymmetrical event in which the relationship between the teacher and the students is not egalitarian (CAZDEN, 1988, 1992). As such, the lesson is perceived as a sensitive speech event that threatens the interlocutors' face, thus leading them to use politeness strategies whose function is saving face (PAVLIDOU, 2001; VARDI-RATH, 2002). Politeness is defined in terms of Brown and Levinson's model (1987) as the intentional, strategic behavior of an individual meant to satisfy self and other face-wants in case of a threat, enhanced via discourse strategies.

\subsubsection{The methodological framework}

ISEA combines qualitative and quantitative analyses of the participant structure in asymmetric speech events (VARDI-RATH; BLUMKULKA, 2005). A coding scheme comprising quantifiable discourse categories that stem from the data is built for event analysis. The categories are about recurring speech acts or strategies that relate to the power relations and politeness dimensions of the analyzed interaction.

\subsubsection{Text analysis}

The analysis resulted in the identification of two categories: Functional aspects of the interaction and indirect speech acts. Functional aspects of the interaction were expressed in the text in various ways. First, the teacher produces 26 of the 33 utterances computed in the text. This shows that the teacher is holding the floor most of the time. Second, 10 out of the teachers' 26 utterances comprise a question. Eight questions are test questions, checking whether the students know the answers 
(DILLON, 1988) to the question regarding the bread ingredients. Two of the 10 questions are indirect command questions (GOODY, 1978) (e.g., "Karen, do you want to fall and break your back?" (line 32).

It seems that the teacher does not expect the students to answer these questions. Why then does she use interrogatives? It is plausible to assume that questions have a linguistic power that enables the teacher to perform an act of control (RICHARDS; LOCKHART, 1994). However, control may establish an atmosphere of threat to the students' face as the following utterance shows: "What else does it have? Amit?" (line 8). The test-like nature of the questions hints at an atmosphere of testing and a threat to the pupils' face. When the teacher addresses the question to Amit, he is subjected to a public scrutiny (ERICKSON; MOHATT, 1982), and his answer will be accepted or rejected according to the teacher's decision.

In addition, even though 9 of the teacher's 26 utterances are apparently informative, they do not function as such. Thus, for example, when the teacher says "Effie's gone back to his seat without permission" (line 9), she informs the students about Effie's actions. However, it seems that in line 9 the teacher actually intends to scold Effie, rather than communicate information. Why does the teacher refrain from addressing Effie directly? How does this indirect address affect Effie or other students in the class?

Before we answer these questions, we should take another look at the teacher's utterances which can also be categorized in terms of Anward's (1997) distinction between activity talk (i.e., talk defining the social activity in the classroom, including lesson management, discourse flow, and the relations between the participants) and topic talk (i.e., talk that is responsible for the development of the content studied in the lesson).

Fourteen of the 26 teachers' utterances belong to the are examples of activity talk, which defines the social activity in the classroom, and 12 utterances are examples of topic talk (i.e., teaching about the major food groups). The high frequency of activity talk in the lesson is evident. According to this quantitative description, it would seem that the teacher is involved in organizing and managing the lesson no less than in the learning processes themselves. 
These two talk types operate according to a different metalinguistic scheme. Topic talk operates according to the I.R.E sequence (i.e., the teacher initiates an act, the student responds, the teacher evaluates the response) (MEHAN, 1979). The meta-linguistic scheme manifested in activity talk might vary. In our case, the teacher presents a request (e.g., "Effie, stand up", line 10), expecting no response from the students. During the lesson the teacher shifts from topic talk to activity talk and the students are expected to recognize this transition and react accordingly. However, the abrupt transitions from topic talk to activity talk, which break the basic I.R.E sequence, are not announced openly. Consequently, they are liable to confuse and distract the students. Example 2 illustrates this abrupt and unexpected transition:

Example 2 - Transition from topic talk to activity talk::

7. Teacher: Only vitamins?

8. Teacher: What else does it have, Amit?

9. Teacher: Effie's gone back to his seat without permission.

10. Teacher: Effie, stand up.

11. Teacher: Yes.

12. Student: Carbohydrates.

13. Teacher: Carbohydrates, good.

The second category characteristic of the text is indirect speech acts (i.e., when the literal meaning of the utterance is different than its communicative intention) (SEARLE, 1975). Pragmatics deals with bridging the gap between the utterance meaning and the speaker meaning (GRICE, 1975). For example, when the teacher says: "Effie's gone back to his seat without permission" (line 9), we assume that she wishes to rebuke Effie. To save her face, the teacher chooses to speak indirectly, presenting herself in a moderate and positive light, instead of uttering a harsh rebuke. The concept of politeness may be used to explain the use of linguistic strategies to save the participants' face during the interaction (THOMAS, 1995).

Our analysis shows that indirectness characterizes the teacher's utterances. In a third grade lesson, it might come at the expense of clarity 
and confuse some of the students. For example, the teacher uses a question form to reprimand Karen: "Karen, do you want to fall and break your back?" (line 32). It seems that Karen managed to identify the teacher's meaning, and therefore she does not respond, even though a question has been addressed to her.

In our text, politeness is constructed via mitigation (lines 30-35), and the use of the first person plural. (e.g., "Teacher: we want to keep our bodies healthy, right?" (line 33. See also lines 20, 22). The first person plural is often ascribed in sociolinguistics to relationships of proximity and solidarity (SCOLLON; SCOLLON, 1995). However, when the teacher says "we haven't gotten there yet" (line 20), she actually tries to stop a student from advancing on his own. In Example 3, the student expresses his insight that bread contains all the food ingredients, but the teacher ignores this discovery.

Example 3 - The teacher curbs the student's curiosity:

19. Student: Orna, in the Food Ingredient Chart on page eleven, there's everything in bread

20. Teacher: We haven't gotten there yet, haven't gotten there yet

21. Student: But there's everything in bread there.

22. Teacher: Just a second. We'll get there in a second.

23. Student: I've already gotten there.

Example 3 shows that in response to the student's insight, the teacher stresses that the student's fast pace does not suit her agenda to describe each ingredient separately, and only finally reaches the point (i.e., bread does indeed contain all the food ingredients). She therefore curbs him but uses "we", thus mitigating her request by claiming that it is done for the good of the students.

To recapitulate, following ISEA, the text analysis shows that the teacher uses various discourse strategies to consolidate her power during the lesson. The teacher's dominance comes to the fore in her holding the floor and in her extensive exploitation of the linguistic power of posing questions. It is further manifested in her broad use of activity talk and in the abrupt transitions between topic and activity talk. These shifts are 
liable to confuse the students. The teacher's use of various politeness strategies, such as the first person plural and mitigation, indicate that she expends a great deal of effort to gain and maintain control.

\subsection{The Four World Method (FWM)}

\subsubsection{Theoretical framework}

The Four World Method (FWM) aims at exploring how interlocutors position, or locate themselves in interactional discourse (DAVIES; HARRÉ, 1990; LANGENHOVE; HARRÉ, 1999). The method is inspired by two functionalist approaches to discourse analysis (SCHIFFRIN, 1994): Linguistic anthropology (DURANTI, 1997) and institutional conversation analysis (ICA) (DREW; HERITAGE, 1992). In addition, it is also based on a current definition of discursive positioning (BAMBERG, 2004; KUPFERBERG; GREEN, 2005; in press).

The functionalist approaches listed above view language resources (e.g., syntactic structures, figurative and non-figurative lexical items and phrases, pronouns, reported speech, etc.) as tools used by interlocutors in the co-construction of interpersonal communication and self. For example, in the classroom discourse analyzed in this paper, the teacher's questions and directives are salient linguistic resources which she uses to manage the interaction (THORNBORROW, 2002). The use of these language resources also shows that she positions herself vis-à-vis her students as the person who is in charge.

Following linguistic anthropology (DURANTI, 1997), the first functionalist approach, we assume that discourse is locally produced in a specific context and is reflexively related to it. Inspired by ICA (DREW; HERITAGE, 1992), the second functionalist approach, we assume that interlocutors co-produce meaning in discourse and therefore we have to examine the text turn-by-turn in order to identify the interactional dimensions of an ongoing conversation.

Positioning is a discursive activity that was originally defined as how narrators locate themselves in conversation in relation to one another. This concept constitutes "a dynamic alternative to the more static idea of role” (LANGENHOVE; HARRÉ, 1999, p. 14). Espousing 
Bamberg's analysis of positioning (2004), and the definition of chronological and narrative time (see an overview in Kupferberg; Green, 2005), we assume that interlocutors use self-displaying resources that enable them to position (DAVIES; HARRÉ, 1990), or locate, themselves in discourse vis-à-vis significant others in the past world of experience (e.g., a student tells a personal story during the lesson), which is unfolded in the present (i.e., the ongoing classroom interaction).

FWM (KUPFERBERG; GREEN, 2005; in press) also shows that sometimes interlocutors shift the focus of the talk to possible future worlds where they attempt to change past experience (e.g., a student talks about his future plans during the lesson). The fourth world is an interpretive interface in which the researcher examines the interlocutors' trans-world journeys (i.e., from the present to the past and the future) and relates them to theories that guide them (BEN-PERETZ; KUPFERBERG， 2007; KUPFERBERG; BEN-PERETZ， 2004; KUPFERBERG; GREEN, 2005).

\subsubsection{Methodological framework}

The method of analysis (KUPFERBERG; GREEN, 2005) is a step-by-step heuristic procedure based on the FWM showing how the text is broken down into the interlocutors' present, past and future worlds. Subsequently, the text is reassembled in a fourth world - an interpretive interface that establishes a bridge between the micro and macro-analytic perspectives. In our text, for example, the teacher and the students position themselves via language resources mainly in the ongoing classroom activity in the present. The interlocutors' past and future worlds of experience are barely reached. Our fourth interpretive world is presented in the next subsection.

FWM is guided by the principle that research should be actionoriented and applicable in the very context in which the data was collected (KUPFERBERG; GREEN, 2005). The advantages of this method are two-fold. First, it offers a procedure for dividing the complexity of discourse into well-defined parts that are later reconstructed in an interpretive interface. Second, this reconstruction links the micro and macro-analytic perspectives on discourse. 


\subsubsection{Text analysis}

It is not difficult to see that the text analyzed in this paper is mainly located in the present where the teacher and the students position themselves vis-à-vis each other. The teacher locates herself in relation to the students as an authoritative figure in charge of instruction and class management and she decides which of the two should be focused on. The students are positioned as obedient and compliant. These positionings are discursively expressed via a turn allocation system that is teacher-centered. The teacher uses questions and directives - two linguistic resources that enable her to control the interaction.

The only instances of temporal shift to the past and the future are displayed in lines 26-30, where the teacher decides to change the temporal focus. As for the nature of these shifts, in both cases the shift is carried out to accomplish tasks that are on the teacher's mind. They do not provide the students with an opportunity to generate a meaningful discussion about their own past experience or focus on possible and attractive future landscapes.

To recapitulate, examined from the FWM perspective, the text is teacher-oriented. It neither provides the students with a space to relate to their own experience, nor does it enable them to plan or dream about the future. Such temporal shifts are crucial for inter and intra-personal development of self and other-awareness and insights (KUPFERBERG; GREEN, 2005).

\subsection{Grounded Theory (GT)}

\subsubsection{Theoretical framework}

The Grounded Theory approach in social sciences was initially developed by Glaser and Strauss (1967). Glaser defines GT as "the systematic generating of theory from the data, which in itself is systematically obtained from social research" (GLASER, 1978, p. 2). This approach aims at understanding personal and social phenomena using an inductive process of eliciting the main categories of meaning from the data and identifying the interconnections between them until a theory emerges. 


\subsubsection{Methodological framework}

A GT study begins with an open-ended question about a phenomenon. Empirical data are collected to represent the phenomenon, and the GT is formed by gradually coding the empirical data. Strauss and Corbin (1990) suggest three phases of data coding. The first phase is open coding, when the empirical data is segmented into sentences or paragraphs. The researcher notes the main idea of each sentence or paragraph and forms categories and subcategories of meaning based on recurring ideas.

During axial coding, the second phase, the researcher establishes a pattern, order or inter-relationships among the categories. In order to establish such order, Strauss and Corbin (1990) recommend identifying the implied casual relationship among the various categories. For example, the researcher can suppose that some categories represent the reasons or origins underlying the studied phenomena. Others represent its symptoms, manifestations, results or implications. This metaorganization of the categories based on abstracting factors that are present in any phenomena can help the researcher form his local theory. Selective coding is the third phase, when the researcher identifies a story line based on the now interlinked categories, and proceeds to write the grounded theory.

The GT actual phases of coding might vary among researchers, but their dynamics is essentially the same. The researcher constantly compares the categories that emerge during data analysis, looking for differences, similarities and other types of relationship like inclusion, exclusion and overlapping. Through constant comparison the researcher gradually forms hypotheses about the meaning of the categories and inter-relationships among them until a theory emerges.

\subsubsection{Text analysis}

What epistemology do third grade students learn through a science lesson about the major food groups? The following analysis aims at providing an answer to this question. Epistemology is "about the nature of knowledge and knowing, including definitions of knowledge, 
how knowledge is constructed, and how knowledge is evaluated" (HOFER; PINTRICH, 1997, p. 88).

The analysis is grounded in several contextualizing suppositions. First, students attend school in order to learn something. Second, science lessons are usually about learning some scientific facts, ideas and/or theories and procedures. Thirdly, when one studies science (or any other discipline) one also acquires general ideas about the meaning of knowledge and knowing in science and in general.

\subsubsection{Open coding}

During this phase, two categories emerged: knowledge domains and ways of knowing. The former category is further subdivided into scientific and social subcategories. Example 4 illustrates the lines to which the subcategory scientific was attached.

Example 4 - Foring the subcategory "scientific":

1. Teacher: So, if that's the case, what can we say - what ingredients are there in bread?

2. Student: Vitamins.

The social subcategory (i.e., rules of appropriate classroom behavior) is manifested in line 9: "Teacher: Effie's gone back to his seat without permission", since we assume that the teacher focuses on classroom behavior here.

As for ways of knowing, the second category, the analysis shows that it is also subdivided into two subcategories. The first is being sent by the teacher to discover information by looking at the tables. This subcategory is expressed in "Teacher: Do you see bread in the Vitamins column?" (line 4). 'The second subcategory is listening to the teachers' descriptions of students' behavior and being told or 'rhetorically asked' about the meanings or consequences of this behavior. Example 5 presents the lines to which this subcategory was attached:

Example 5 - Categorizing the text: 
27. I've already called on you several times today. I wanted to hear an answer and I

28. Haven't managed to get an answer.

29. But talk - you talk.

\subsubsection{Axial coding}

Each knowledge domain is reached via specific ways of knowing. Scientific knowledge about the major food groups is learned by listening to the teacher's instructions that monitor the process of looking at the table. Social knowledge related to appropriate classroom behavior is learned by listening to the teacher reprimanding students who strayed and describing their improper behavior by asking for explanation or talking about the consequences of such behavior. For both knowledge domains, the only source of information is the teacher. The teacher is an authority that monitors ways of knowing. Example 6 illustrates this point.

Example 6 - The teacher monitors ways of knowing:

19. Student: Orna, in the Food Ingredient Chart on page eleven, there's everything in bread

20. Teacher: We haven't gotten there yet, haven't gotten there yet

\subsubsection{Selective coding}

Apparently, the teacher, in conducting a lesson on the major food groups, is urging the third graders to explore the major food groups and in this process construct their own knowledge. Actually, the teacher merely instructs the students to identify the major food groups that are present in bread by looking at a table: "Do you see bread in the Vitamins column? Do you see bread?" (line 4). Therefore, the so called exploration is only mechanical, since nothing is done apart from finding the right answers in the table. The teacher does not attempt to relate the meaning of food groups to pertinent issues such as health promotion and body 
building. Furthermore, students are not allowed to advance on their own, as Example 3 illustrates.

The teacher also instructs the students about what appropriate classroom behavior is. Instruction is performed by pointing at unruly students in the presence of their classmates and asking rhetorical questions or using negative parallels. It is plausible to assume that the teacher's verbal behavior ridiculed and embarrassed the students. Example 7 illustrates this point:

\section{Example 7 - Pointing at unruly students:}

27. Teacher: I've already called on you several times today. I wanted to hear an answer and I

$28 . \quad$ haven't managed to get an answer.

29. Teacher: But talk - you talk.

To recapitulate, examined via the GT lens, the lesson focuses on two knowledge domains: the scientific (i.e., the major food groups), and the social (i.e., appropriate classroom behavior). These ways of knowing are monitored by the teacher. In fact, in the classroom interaction presented in Example 1, there are only two sources of information: the teacher and the table. The students are not allowed to express their voice. Knowing is achieved by fulfilling the teacher's instructions or getting reprimanded. Consciously or unconsciously, the teacher keeps transmitting contradictory messages that have both explicit and implicit meanings. The students are sent to explore a table and find the major food groups, but the exploration is mechanical. The students are reprimanded about their unfit behavior but the questions are rhetorical.

We can conclude that the notions of knowledge and knowing that emerge from the lesson are rigid. Knowledge is something one gains by following the expert's (i.e., the teacher's) instructions. The expert tells the students to explore data, but all they do is identify the right answers. If students disobey the instructions, they are reprimanded or ridiculed. Either way, they do not have a say in the matter. 


\section{DISCUSSION}

Our study of classroom discourse was guided by the following question: What is the contribution of a multiple-method design to the understanding of a classroom interaction? To answer the question, we used three discourse-oriented methods that provided three text analyses. The analyses showed that the classroom interaction that we analyzed is asymmetrical - exclusively dominated by teacher talk. This finding is not surprising. It supports Peled-Elhanan and Blum-Kulka's (2006) findings that in the Israeli context, teachers mostly engage in pseudo-dialogue or monologue disguised as a dialogue.

The present article further foregrounds different dimensions of the asymmetry identified in the analyzed text. ISEA illustrates social dimensions of the interaction through the discourse strategies employed by the teacher in order to consolidate her power during the lesson (e.g., abrupt transitions between topic and activity talk). In addition, this method reveals various face-saving politeness strategies employed by the teacher.

FWM foregrounds the experiential aspect of the interaction. It shows that the teacher's authoritative positioning in the here and now does not allow the students to make meaningful discursive journeys to their worlds of past experience and/or hypothetical future worlds. GT emphasizes the epistemological dimension by illuminating the limited and mechanical pattern of knowledge acquisition enforced by the teacher.

The three methods further show that the teacher's discursive productions contain contradictory pedagogical and communicative messages. ISEA shows how the teachers' use of indirectness (e.g., using the form of question instead of order) comes at the expense of clarity in the lesson. Second, politeness strategies (e.g., the use of the first person plural and mitigation), which usually express solidarity, are exploited to gain control.

FWM stresses that the teacher's control of temporal shifts in the classroom discourse was carried out to satisfy her needs, and did not provide the students with a space where they could express their voice. 
GT shows that the teacher uses pseudo search and explore didactics which directs the students to look for information, but the search is merely mechanical. She also uses a pseudo you figure it out strategy which urges the students to explain their behavior but because the questions are rhetorical, no response is expected.

The joint picture that emerges out of the multiple-method design shows that the social, experiential and epistemological aspects of the classroom interaction are interrelated: the teacher holds the floor and a lot of her utterances are informative, which shows that she is the one who knows the major sources of information. The teacher controls the interaction in the here and now, which doesn't allow the students to voice their knowledge or relate to past and future experiences.

The three analyses use different means to probe the text, and thus they complement as well as validate each other. Focusing on language resources, ISEA and FWM show how the teacher consciously or unconsciously uses language resources to control her class. GT probes the content of the interaction, and shows that the epistemological dimensions of the learning process are mechanical and do not enhance explorative ways of knowing. Together, the three methods provide a rigorous trust-worthy (LINCOLN; GUBA, 1998) description and interpretation of the classroom interaction.

We claim that the multiple-method design employed in this study illuminates implicit aspects of the classroom puzzle, the mysterious ways in which teachers and students interact about knowledge (BRUNER, 1996, p. 55). Explicitly, the teacher and students are interacting about the major food groups. Implicitly, the students learn that the teacher and the learning materials are the only sources of information. They further learn that in the classroom knowing is completely monitored by the teacher. She is the one who decides what, how and when one is allowed to know.

This interpretation raises another question. Does the power the teacher exercises in the classroom come from a position of strength? Our analyses reveal a paradox concerning the teacher's control. Institutionally, the teacher's power is supposed to be overt and deeprooted, but in fact it seems that her authority is not unequivocal, and therefore she is obliged to use various language strategies to sustain her control. 
Our explanation lies in the teacher's need for face-saving. We assume that nowadays, in an era of knowledge explosion, the teacher's face is constantly threatened. As a result, she cannot rely solely on the formal authority that has been vested in her by the establishment. She is compelled to continually negotiate her authority with the students.

In conclusion, our study has theoretical, methodological and practical implications. Theoretically, the link between the epistemological, the experiential and the social dimensions of classroom interaction that emerges from multiple text analyses can be further explored in educational and non-educational institutional settings. Methodologically, the use of a multiple-method perspective can open new venues for the study of interaction in education and elsewhere. Finally, the practical implication of the study should be focused on "changing patterns of participation" (GEE; GREEN, 1998) and bringing about better teaching and learning practices. Educators should be creative about designing new models of teacher-students interaction that may enhance the growth and development of the students.

\section{REFERENCES}

ADGER, C. T. Discourse in academic settings. In: SCHIFFRIN, D.; TANNEN, D.; HAMILTON, H.E. (Eds.). The handbook of discourse analysis. Padstow, Cornwall: Blackwell. p. 503-517. 2001.

ANWARD, J. Parameters of institutional discourse. In: GUNNARSSON, B. L.; LINELL, P.; NORDBERG, B. (Eds.). The construction of discourse. London; New York: Longman, 1997. p. 128-150.

AUSTIN, J. How to do things with words. Oxford: Oxford University Press, 1962.

BAMBERG, M. Considering counter narratives. In: BAMBERG, M.; ANDREUS, M. (Eds.). Considering counter-narratives : narrating, resisting, making sense. Amsterdam: John Benjamins, 2004. p. 351-371.

BEN-PERETZ, M.; KUPFERBERG, I. Does teachers' negotiation of personal cases in an interactive cyber forum contribute to their professional learning?

Teachers and teaching: theory and practice, v. 13, p. 125-143, 2007. 
BLOOME, D.; CARTER, S. P.; CHRISTIAN, B. M.; OTTO, S.; STUARTFARIS, N. Discourse analysis \& the study of classroom language $\&$ literacy events: a microethnographic perspective. Mahwah, New Jersey: Lawrence Erlbaum, 2005.

BROWN, P.; LEVINSON, S. Politeness: some universals in language usage. Cambridge: Cambridge University Press, 1987.

BRUNER, J. The culture of education. Cambridge, MA: Harvard University Press, 1996.

CAZDEN, C.B. Classroom discourse: the language of teaching and learning. Portsmouth, NH: Heinemann, 1988.

Whole language plus: essays on literacy in the United States and New Zealand. New York: Teachers College Press, 1992.

DASCAL, M. Pragmatics and philosophy of mind: thought in language. Amsterdam; Philadelphia: John Benjamins, 1983.

DAVIES, B.; HARRÉ, R. Positioning: the discursive production of selves. Journal for the theory of social behavior, v. 20, p. 43-63, 1990.

DILLON, J.T. Questioning and teaching: a manual practice. New York: Teachers College Press, 1988.

DREW, P.; HERITAGE, J. Analyzing talk at work. In: DREW, P.; HERITAGE, J. (Eds.). Talk at work: interaction in institutional settings. New York: Cambridge University Press, 1992. p. 1-65.

DURANTI, A. Linguistic Anthropology. New York: Cambridge University Press, 1997.

EDWARDS, V. Teacher-student talk in multi-ethnic classrooms. In: DAVIES, B.; CORSON, D. (Eds.). Encyclopedia of language and education: oral discourse and education. V. 3. London: Kluwer Academic Publishers, 1999. p. 95-103.

; WESTGATE, D. P. G. Investigating classroom talk. London: The Palmer Press, 1994.

ERICKSON, F; MOHATT, G. Cultural organization of participation structures in two classrooms of Indian students. In: SPINDLER, G. (Ed.). Doing the ethnography of schooling. New York: Holt, Rinehart \& Winston, 1982. p.132174. 


\section{2}

GEE, J. P.; GREEN, J. L. Discourse analysis, and social practice: a methodological study. Review of research in education, v. 23, p. 119-169, 1998.

GLASER B. G. Theoretical sensitivity: advances in the methodology of grounded theory. Mill Valley, CA: Sociology Press, 1978.

1967.

; STRAUSS, A. The discovery of grounded theory. Chicago: Aldine,

GOFFMAN, E. The presentation of self in everyday life. New York: Anchor Books, 1959.

Interaction ritual: essays on face to face behavior. New York:

Doubleday, 1967.

Forms of talk. Philadelphi: University of Pennsylvania Press, 1981.

GOODY, E. Towards a theory of questions. In: (Ed.). Questions and politeness. Cambridge: Cambridge University Press, 1978. p. 17-43.

GRICE, H.P. Logic and conversation. In: COLE, P.; MORGAN, J.; (Eds.). Speech acts. V. 3: syntax and semantics. New York: Academic Press, 1975. p. 41-58.

GUMPERZ, J. Discourse strategies. Cambridge: Cambridge University Press, 1982.

Contextualization and understanding. In A. Duranti; C. Goodwin (Eds.), Rethinking Context: Language as an Interactive Phenomenon .Cambridge: Cambridge University Press, 1992. p. 229-252.

HOFER, B.K.; PINTRICH, P. R. Epistemological theories: the development of beliefs about knowledge and knowing and their relation to learning. Review of educational research, v. 67, 1997. p. 88-140.

HOLSTEIN, J. A.; GUBRIUM, J. F. The self we live by: narrative identity in a postmodern world. New York: Oxford University Press, 2000.

HYMES, D. Models of the interaction of language and social life. In: GUMPERZ , J.; HYMES, D. (Eds.). Directions in Sociolinguistics: the ethnography of communication. New York: Holt, Rinehart and Winston, 1972. p. 35-72.

Ethnography, Linguistics, narrative inequality: towards an understanding of voice. London: Taylor \& Francis, 1997. 
JACKSON, P. W. Life in classrooms. New York: Holt, Reinhart \& Winston, 1968.

KUPFERBERG, I.; GREEN, D. Narrators defend their side of the story metaphorically at troubled narrative junctions. Narrative inquiry. (in press)

; GREEN, D. Troubled talk: metaphorical negotiation in problem discourse. Berlin: Mouton de Gruyter, 2005.

KUPFERBERG, I.; BEN-PERETZ, M. Emerging and experienced professional selves in cyber discourse. In: VRASIDAS, C.; GLASS, G. V. (Eds.). Online professional development for teachers. Current perspectives on applied information technologies: online professional development. Connecticut, USA: IPA, 2004. p. 105-121.

LANGENHOVEN, L. V.; HARRÉ, R. Introducing positioning theory. In: HARRÉ, R.; LANGENHOVEN, L. V. (Eds.). Positioning theory: moral contexts of intentional action. Oxford: Blackwell, 1999. p. 14-31.

LINCOLN, Y. S; GUBA E. G. Paradigmatic controversies, contradictions and emerging confluences. In: DENZIN, N.; LINCOLN, Y. S. (Eds.). Handbook of qualitative research. Thousand Oaks, CA: Sage, 1998. p. 163-188.

MEHAN, H. Learning lessons. Cambridge, MA: Harvard University Press, 1979.

PAVLIDOU, T. S. Politeness in the classroom? Evidence from a Greek high school. In: BAYRAKTAROGLU, A.; M. SIFIANU (Eds.). Linguistic

Politeness across Bounderies: the case of Greek and Turkish. Amsterdam: Benjamins, 2001. p. 105-136.

PELED-ELHANAN, N; BLUM-KULKA, S. Dialogue in the Israeli classroom: types of teacher-student talk. Language and education, v. 20, p. 110-127, 2006.

QUIRK, R.; GREENBAUM, S.; LEECH, G.;SVARTNIK, J. A comprehensive grammar of the English language. New York: Longman, 1985.

RICHARDS, J.C.; LOCKHART, C. Reflective teaching in second language classrooms. Cambridge: Cambridge University Press, 1994.

ROGERS, R.; MALANCHARUVIL-BERKES, E.; MOSLEY, M.; HUI, D.; O'GARRO-JOSEPH, G. Critical discourse analysis in education: a review of the literature. Educational research, v. 3, p. 365-416, 2005. 
SACKS, H. Lectures on conversation. V. 1-2. JEFFERSON, G (Ed.). Oxford: Blackwell, 1992 [1964-1972].

SCHEGLOFF, E. A.; SACKS, H. Opening up closings. Semiotica, v. 7, p. 289327, 1973.

SCHIFFRIN, D. Approaches to discourse. Oxford: Blackwell Publishers, 1994.

SCHWANDT, T. A. Dictionary of qualitative inquiry. $2^{\text {nd. }}$ edition. Thousand Oaks, CA: Sage, 2001.

SCOLLON, R.; SCOLLON, S. Intercultural communication: a discourse approach. Oxford: Basil Blackwell, 1995.

SEARLE, J. Speech acts. Cambridge: Cambridge University Press, 1969. . Indirect speech acts. In: COLE; P.; MORGAN, J. (Eds.). Speech acts. V. 3: syntax and semantics. New York: Academic Press, 1975. p. 59-82.

STRAUSS, A.; CORBIN, J. Basics of qualitative research: grounded theory procedures and techniques. Thousand Oaks, CA: Sage, 1990.

TASHAKKORI, A.; TEDDLIE, C. Handbook of mixed methods in social and behavioral research. Thousand Oaks, CA: Sage, 2003.

TEN HAVE, P. Doing conversation analysis: a practical guide. London: Sage, 1999.

THOLANDER, M.; ARONSSON, K. Doing subteaching in school work: positionings, resistance and participation frameworks. Language and education, v. 17, p. 208-234, 2003.

TITCHER, S.; MEYER, M.; WODACK, R.; VETTER, E. Methods of text and discourse analysis. London: Sage, 2000.

THOMAS, J. Meaning in interaction: an introduction to Pragmatics. New York: Longman, 1995.

THORNBORROW, J. Power talk: language and interaction in institutional discourse. London: Longman, 2002.

VAN DIJK, T. A. The study of discourse. In: . (Ed.). Discourse studies: a multidisciplinary introduction. V. 1: Discourse as structure and process. London: Sage, 1997. p. 1-34. 
A critical discourse analysis. In: SCHIFFRIN, D.; TANNEN, D. ; HAMILTON, H. E. (Eds.). The handbook of Discourse Analysis. Padstow, U.K.: Blackwell, 2001. p.353-371.

VARDI-RATH, E. The role of discourse in the construction of social reality in the classroom: Control and politeness in teacher talk. PhD. Thesis submitted to the senate of the Hebrew University in Jerusalem, 2002.

; BLUM-KULKA, S. The lesson as an asymmetric speech event: a study of the participant structure in the Israeli classroom. In: KUPFERBERG, I; OLSTEIN, E. (Eds.). Discourse in Education: researching educational events. Tel-Aviv: Mofet Institution, 2005. p. 385-417.

WELLS, G. Dialogic inquiry: towards a sociocultural practice and theory of education. New York: Cambridge University Press, 1999.

YOUNG, R. Social science theory in researching language and education. In: HORENBERGER, N. H.; CORSON, D. (Eds.). Encyclopedia of language and education. V. 8. London: Kluwer Academic Publishers, 1999. p.11-20.

Received 12/12/07. Accepted 19/09/08.

Título: Fazendo sentido da interação em sala de aula através de uma proposta multimétodo: dimensões sociais, experienciais e epistemológicas

Autor: Irit Kupferberg; Sarah Shimoni; Esther Vardi-Rath

Resumo: Esse artigo explora a contribuição de uma proposta multi-médodo para o estudo das interações em sala de aula. Os arcabouços teórico e metodológico de três métodos de construtivistas de orientação discursiva (i.e., Análise de Eventos de Fala Institucionais, Método dos Quatro Mundos, e Teoria de Base) são resumidos e o mesmo texto é submetido a três análises textuais independentes. O artigo mostra que a proposta multi-método conduz a descoberta de significados implícitos relacionados aos aspectos sociais, experienciais e epistemológicos da interação em sala de aula.

Palavras-chave: interação em sala de aula; análise do discurso; proposta multi-método; posicionamento; grounded theory.

Titre: Du sens dans l'interaction en salle de classe à travers une proposition multiméthode : dimensions sociales, d'expérimentation et épistémologiques

Auteur: Irit Kupferberg; Sarah Shimoni; Esther Vardi-Rath

Résumé: Cet article exploite la contribution d'une proposition multi-méthode pour l'étude des interactions en salle de classe. La constitution théorique et méthodologique de trois méthodes de constructivistes d'orientation discursive (i.e., Analyse d'Événements de la Parole Institutionnels, Méthode des Quatre Mondes et Théorie de Base) sont résumés et le même texte est soumis à trois analyses textuelles 


\section{6}

indépendantes. L'article démontre que la proposition multi-méthode conduit à la découverte de significations implicites en rapport aux aspects sociaux, d'expérimentation et épistémologiques de l'interaction en salle de classe.

Mots-clés: interaction en salle de classe; analyse du discours ; proposition multiméthode ; positionnement ; théorie de base.

Título: Haciendo sentido de la interacción en aula a través de una propuesta método múltiple: dimensiones sociales, experienciales y epistemológicas

Autor: Irit Kupferberg; Sarah Shimoni; Esther Vardi-Rath

Resumen: Ese artículo explora la contribución de una propuesta método múltiple para el estudio de las interacciones en aula. Los esbozos teórico y metodológico de tres métodos de constructivistas de orientación discursiva (i.e., Análisis de Eventos de Habla Institucionales, Método de los Cuatro Mundos, y Teoría de Base) son resumidos y el mismo texto es sometido a tres análisis textuales independientes. El artículo muestra que la propuesta método múltiple conduce al descubrimiento de significados implícitos relacionados a los aspectos sociales, experienciales y epistemológicos de la interacción en aula.

Palabras-clave: interacción en aula; análisis del discurso; propuesta método múltiple; posicionamiento; teoría de base. 